\title{
(Ne)rozhodovanie o súlade ústavného zákona s ústavou
}

\author{
Balog, B.*
}

BALOG, B.: (Ne)rozhodovanie o súlade ústavného zákona s ústavou. Právny obzor, 104, 2021, č. 2, s. $99-115$.

(Non-)decision making on the conformity of the constitutional act with the constitution. The article provides a point of view of the regulation stipulating from 1 January 2021 that the Constitutional Court of the Slovak Republic does not decide on the conformity of a constitutional law with the constitution. This view is not from the position of the Constitutional Court of the Slovak Republic, as might be expected, but the article presents a view through the exercise of those powers of the National Council of the Slovak Republic that require a constitutional majority. The idea is to point out inflation, relativization and the fallacy of the constitutional majority. This exposes the core of the constitution to a threat against which there must be a protection in place in a democratic and legal state.

Key words: National Council of the Slovak Republic, Constitutional Court of the Slovak Republic, material core of the Constitution, constitutional majority

\section{Úvod}

Ústavný zákon č. 422/2020 Z. z. priniesol rozsiahly zásah do ústavnej úpravy súdnej moci, pričom tento sa týkal tak súdov Slovenskej republiky, ako aj Ústavného súdu SR. Mnohé zmeny Ústavy Slovenskej republiky (d’alej len ústava) si zaslúžia osobitnú pozornost' a iste sa jej skôr alebo neskôr dočkajú. ${ }^{1}$ Osobitnú pozornost' si zaslúži aj doplnenie čl. 125 ods. 4 ústavy o vetu, podl'a ktorej „Ústavný súd nerozhoduje ani o súlade ústavného zákona s ústavou."

Prvoplánový pohlad na výslovnú ústavnú úpravu toho, že Ústavný súd SR nerozhoduje ani o súlade ústavného zákona s ústavou v spojení s účinnost'ou takejto úpravy od 1. januára 2021 by navodil otázku, či Ústavný súd SR právomocou rozhodovat' o súlade ústavného zákona s ústavou do 31. decembra 2020 disponoval. Ak áno, a ak by s takouto právomocou nakladal aktivisticky a nadužíval by ju, tvrdá reakcia jediného ústavodarného orgánu by bola na mieste. Ak ale takáto právomoc súčast'ou kompetenčného inštrumentária Ústavného súdu SR do 31. decembra 2020 nebola, aký rozdiel nastal v porovnaní so stavom pred 1. januárom 2021?

Dôležitejšia otázka je, či by mala v demokratickom a právnom štáte existovat’ právomoc/možnost' rozhodovat' o súlade ústavného zákona s ústavou, osobitne ak ide o ústavu minimálne rigidnú. Ak by tomu tak bolo, ktorý ústavný orgán a za akých okolností a podmienok by ňou mal disponovat'. Ak by to tak nebolo, vyvstáva otázka, ako inak ochránit' demokratický a právny štát a jeho ústavu pred formalizmom (redukcionizmom na formálne chápanie) a odklonom od materiálneho chápania?

\footnotetext{
* Doc. JUDr. Boris B a 1 o g, PhD., vedúci Ústavu teórie a dejín štátu a práva a spoločenskovedných disciplín, Fakulta práva, Paneurópska vysoká škola.

${ }^{1}$ Či už ide o začatie konania o súlade právnych predpisov na návrh senátu Ústavného súdu SR (účinné až od 1. januára 2025), vymenovanie sudcov tohto súdu či ústavné vymedzenie Súdnej rady SR ako ústavného orgánu sudcovskej legitimity.
} 
Výslovná ústavná úprava toho, či ústavný súd alebo iný súdny (ale iný) orgán má alebo nemá právomoc preskúmavat' súlad ústavného zákona s ústavou, je skôr výnimočná.

V praxi, ak takouto právomocou niektorý ústavný súd disponuje, tak ju získal svojou vlastnou rozhodovacou činnost'ou a jej materiálnou legitimitou. Túto ústavný súd dosiahne cez výsledok, ktorý je legitimizovaný tým, že stelesňuje hodnoty, ktoré sú všeobecne akceptovatel'né a sú postavené na presvedčivých argumentoch. ${ }^{2}$

$\mathrm{V}$ rámci úvodu, a aj trochu ako inšpiráciu pre nasledujúci text, spomeniem dva mimoeurópske príklady. Tým prvým je Turecko, kde je preskúmavanie ústavnosti ústavných zákonov kombináciou pozitívnej umožňujúcej ústavnej úpravy dotvorenej judikatúrou ústavného súdu; a tým druhým je India, kde je preskúmavanie ústavnosti ústavných zákonov kombináciou pozitívnej neumožňujúcej ústavnej úpravy prelomenej judikatúrou najvyššieho súdu.

Pôvodná turecká ústava z roku 1961 dodatkom z roku 1971 založila v čl. 147 právomoc tureckého ústavného súdu preskúmavat' formálnu správnost' prijímania ústavných zákonov, ktorými sa mení turecká ústava. Z pôsobnosti ústavného súdu bola ústavodarcom vylúčená vecná stránka ústavných zákonov. Takéto vymedzenie právomoci modifikoval svojimi rozhodnutiami samotný ústavný súd, ked’ podstatu materiálneho jadra tureckej ústavy - republikánsku formu vlády - chápal ako formálnu náležitost' ústavného zákona, a nie ako vecnú stránku ústavného zákona. Tým si ústavný súd právomoc preskúmavat' formálnu správnost’ ústavných zákonov rozšíril svojou interpretačnou činnost'ou aj na posudzovanie ústavných zákonov z hl'adiska republikánskej formy vlády.

Právomoc preskúmavat' ústavné zákony zostala tureckému ústavnému súdu zachovaná aj na základe tureckej ústavy z roku 1982, kde je právomoc preskúmavat' ústavné zákony vyjadrená v čl. 148 ods. 1. Táto právomoc ústavného súdu je ale výslovne limitovaná len na posudzovanie formálnej stránky ústavných zákonov, ktorými sa mení turecká ústava. Nevzt’ahuje sa preto na vecnú stránku takýchto ústavných zákonov. ${ }^{3}$

Iný príbeh sa odohral v Indii. Najvyšší súd Indie svojou odvážnou rozhodovacou činnost'ou o zmenách ústavy z roku 1950 vytvoril a rozvinul doktrínu o základnej štruktúre ústavy ako limitu zmien a doplnení existujúcej ústavy.

V rozhodnutí Kesavananda Bharati v. State of Kerala z 24. apríla 1973 Najvyšší súd Indie v súvislosti s preskúmaním 24., 25. a 29. dodatku k ústave rozvinul teóriu o základnej štruktúre ústavy. Právo ústavodarcu menit’ a dopíňat' ústavu nezahŕňa jeho právo nahradit' základnú štruktúru, základný rámec ústavy. Podl’a indickej doktríny základnej štruktúry ústavy môže byt' postupom podla čl. 368 indickej ústavy menená akákol'vek čast', resp. akékol'vek ustanovenie ústavy, ale žiadna čast', resp. žiadne ustanovenie nemôže byt' zmenené tak, aby porušilo základnú štruktúru ústavy.

\footnotetext{
${ }^{2}$ MLSNA, P. Ústavní soudnictví a dělba moci. In: JIRÁSEK, J. (ed.): Ústavní základy soudní moci. Olomouc : Univerzita Palackého v Olomouci, 2009, s. 135-136.

${ }^{3}$ BALOG, B. Materiálne jadro Ústavy Slovenskej republiky. Bratislava : Eurokódex, 2014, s. 125-126.
} 
Základná štruktúra ústavy je v prípade Indie tvorená rôznymi princípmi, ako najmä, ale nielen, prednost'ou ústavy, republikánskou, demokratickou formou vlády, sekulárnym štátom, del'bou moci a federálnym štátnym zriadením. Tie nie sú v ústave z roku 1950 výslovne uvedené, ale vyplývajú z rozhodovacej činnosti Najvyššieho súdu Indie. Najvyšší súd Indie v tomto rozhodnutí odmietol názor, že dodatok k ústave je ústavný len pre splnenie formálnych požiadaviek na jeho prijatie. Súčasne v tomto rozhodnutí vyslovil, že posúdenie dodatku k ústave ako neústavného je možné práve a len v tom prípade, ak porušuje alebo nahrádza základnú štruktúru ústavy. Najvyšší súd Indie tiež vyslovil myšlienku, ktorá je charakteristická pre implicitné materiálne jadro ústavy, že aj ked' parlament ako ústavodarný orgán nie je výslovne limitovaný a formálne môže zmenit', doplnit' alebo zrušit' každé/ktorékol'vek ustanovenie v ústave, nemôže prijat' také zmeny ústavy, ktoré by zasiahli do základných pilierov ústavného systému, z ktorého vyplýva aj autorita samotného parlamentu na uskutočňovanie ústavných zmien. Právo parlamentu menit' ústavu nezahŕňa jeho právo ústavu cestou formálne určenou pre zmeny ústavu nahradit' ústavou novou alebo úplne zničit' ústavu existujúcu. ${ }^{4}$

Doktríny o základnej štruktúre ústavy sa Najvyšší súd Indie držal aj v rozhodnutí Indira Nehru Gandhi v. Raj Narain z 24. júna 1975. V tomto prípade na základe doktríny základnej štruktúry ústavy zrušil ako protiústavný 39 . dodatok k indickej ústave. ${ }^{5}$ Toto rozhodnutie, ktoré sa týkalo politicky citlivej veci, kým tie predchádzajúce „len“ l’udských práv, nenechalo chladnou najsilnejšiu ženu indickej politiky a už v roku 1976 Indickým národným kongresom ovládaný parlament prijal 42. dodatok k indickej ústave. Jeho účelom bolo výslovne vylúčit' dodatky $\mathrm{k}$ ústave $\mathrm{z}$ rozhodovacej činnosti súdov $\mathrm{z}$ akéhokol'vek dôvodu. Takéto obmedzenie súdnej moci smerom $\mathrm{k}$ dodatkom $\mathrm{k}$ ústavy výslovne upravoval čl. 368 ods. 4 indickej ústavy doplnený v roku 1976 a súčasne doplnený odsek 5 zaručoval neobmedzenú ústavnú právomoc indického parlamentu dopín̆at', menit' alebo rušit' ustanovenia $\mathrm{v}$ ústave.

Takáto úprava však „nezlomila“ Najvyšší súd Indie, ktorý aj 42. dodatok podrobil súdnemu prieskumu v prípade Minerva Mills Ltd. v. Union of India a v roku 1980 vyhlásil 42. dodatok k indickej ústave za protiústavný. Najvyšší súd Indie v situácii, ked' výslovná ústavná úprava vylučovala súdny prieskum dodatkov $\mathrm{k}$ ústave a zakladala neobmedzenú právomoc parlamentu ústavu menit’, preskúmal práve toto obmedzujúce ustanovenie, a to s výsledkom, že zasiahlo základnú štruktúru ústavy.

\section{Formálne vyjadrenie nerozhodovania o súlade ústavného zákona s ústavou}

Národná rada SR zaradila vetu o nerozhodovaní Ústavného súdu SR ani o súlade ústavného zákona s ústavou do čl. 125 ods. 4 ústavy. Podl'a jeho znenia do 31. decembra 2020, Ústavný súd SR nerozhodoval o súlade návrhu zákona alebo návrhu iného vše-

\footnotetext{
${ }^{4} \mathrm{~K}$ tomu ALBERT, R. Constitutional Amendment and Dismemberment. In The Yale Juornal of International Law. Vol 43, s. 18-19.

${ }^{5} \mathrm{~K}$ tomu viac, resp. podrobnejšie, GÖZLER, K. Judicial Review of Constitutional Amendments. A comparative Study. Bursa : Ekin Press, s. 88 -95; BALOG, B. Materiálne jadro ústavy. Bratislava : Eurokódex, 2014, s. 67-68.
} 
obecne záväzného právneho predpisu s ústavou, s medzinárodnou zmluvou, ktorá bola vyhlásená spôsobom ustanoveným zákonom, alebo s ústavným zákonom.

Ústava v čl. 125 ods. 4 (výlučne) vyjadrovala, že konanie o súlade má následný charakter a nie preventívny, resp. predbežný charakter. Toto je vyjadrené nemožnost'ou Ústavného súdu SR v konaní o súlade konat' o návrhu právneho predpisu. Následná ochrana ústavnosti v konaní o súlade vyžaduje právny predpis ako spôsobilý predmet posudzovania a nie jeho návrh. Inak povedané, legislatívny proces musí byt' ukončený. Aj ked' to ústava v čl. 125 ods. 4 výslovne neuvádza, tým momentom, ked’ je legislatívny proces na účely konania o súlade ukončený, je moment úradnej publikácie právneho predpisu. ${ }^{6}$ Podstata pôvodného čl. 125 ods. 4 ústavy nebola vo vyjadrení toho, o čom ústavný súd v konaní o súlade nerozhoduje, pretože to vyplýva z čl. 125 ods. 1 ústavy a contrario. Podstata čl. 125 ods. 4 ústavy bola vo vyjadrení následného charakteru konania o súlade. Takáto úprava sa mohla zdat' v počiatkoch ústavy ako nadbytočná, pretože ústava pôvodne upravovala iba následné konania, ale postupným rozširovaním právomocí Ústavného súdu SR aj o preventívne konania úprava konania o súlade ako následného konania $\mathrm{v}$ čl. 125 ods. 4 ústavy získala zmysel.

Doplnením čl. 125 ods. 4 ústavy o novú vetu sa po 1 . januári 2021 v jednom ustanovení ocitli dve normy, ktoré majú rozdielny vecný základ. Obe síce vyjadrujú nerozhodovanie Ústavného súdu SR, ale postaveného na iných pravidlách. Kým v prípade pôvodného znenia čl. 125 ods. 4 ústavy to bolo štádium legislatívneho procesu, tak po rozšírení od 1. januára 2021 je to aj pravidlo štrukturálneho hierarchického vzt’ahu medzi právnymi predpismi. Toto pravidlo ústave v konaní o súlade však nielenže nie je neznáme, práve naopak, na tomto pravidle je postavené celé konanie o súlade a toto pravidlo je vyjadrené v čl. 125 ods. 1 ústavy ako nevyhnutný predpoklad konania o súlade - existencia vnútornej štruktúry právneho poriadku s vertikálnymi vzt’ahmi. ${ }^{7}$ Existencia horizontálneho vzt'ahu medzi právnymi predpismi vylučuje konanie o súlade medzi nimi. Nie je to v ústave výslovne vyjadrené, ale bezpečne to vyplýva z čl. 125 ods. 1 ústavy.

A práve na horizontálnom vzt'ahu ústavného zákona a ústavy (tiež ústavného zákona) sa Národná rada SR, podl’a mňa, snažila postavit' aj novú normu o nerozhodovaní o súlade ústavného zákona s ústavou. Z formálneho hl'adiska Národná rada SR nesystematicky a nelogicky zasiahla do ústavy. Národná rada SR mala hl'adat' legislatívne riešenie, ako zakomponovat' toto pravidlo do čl. 125 ods. 1 (aj ked' to z neho vyplýva), a nie do čl. 125 ods. 4 ústavy, ktorého účelom je niečo úplne iné, ako stanovovat' to, o čom Ústavný súd SR nerozhoduje.

Čo je však horšie, Národná rada SR po niekol'kých rokoch úspešného presadzovania myšlienky vnútornej hierarchie ústavného systému s prednost'ou noriem (nie ústavy ako

${ }^{6} \mathrm{~K}$ tomu aj MACEJKOVÁ, I. - BÁRÁNY, E. - BARICOVÁ, J. - FIAČAN, I. - HOLLÄNDER, P. SVÁK, J. a kol. Zákon o Ústavnom súde Slovenskej republiky. Komentár. 1. vydanie. Bratislava : C. H. Beck, 2020, s. 658.

${ }^{7}$ K tomu napríklad KROŠLÁK, D. - BALOG, B. - SURMAJOVÁ, Ž. Teória štátu a práva. Bratislava : Wolters Kluwer, 2020, s. 208 a nasl. 
takej!) vytvárajúcich už nie tak neznáme materiálne jadro ústavy, ${ }^{8}$ túto myšlienku (ktorá sa objavila aj v jej ústavodarnej činnosti ${ }^{9}$ ) poprela a vrátila sa $\mathrm{k}$ tvrdému formalizmu.

Aké riziko pre ústavný systém takýto krok predstavuje, je spojené práve s jej vlastnou ústavodarnou činnost'ou.

\section{Národná rada SR konajúca ako ústavodarný orgán}

Konanie o súlade ústavného zákona s ústavou nepokladám za samoúčelné. Jeho podstata nie je v ochrane ústavy ako takej, resp. každej jej normy. Toto konanie má chránit’ spoločenský fundament vyjadrený $\mathrm{v}$ ústave pred takou zmenou, ktorá síce vybavená formálnou legitimitou nemá legitimitu materiálnu. Ústavodarná právomoc jediného ústavodarného orgánu nie je určená na vecne a časovo akékol’vek zmeny ústavy. Ani jediný ústavodarný orgán nezískava legitimitu na zmeny ústavy, ktoré vecne vychyl’ujú ústavu od základov, na ktorých je postavená a ktoré by mohol prijímat' kedykol'vek.

To neznamená, že ústava je alebo by mala byt' zakonzervovaná. K jej tvorbe a jej zmenám je nevyhnutné pristupovat' tak, aby podporovali rozvoj spoločnosti v demokratickom a právnom štáte chápanom materiálne. Ústava musí umožňovat' a podporovat' rozvoj spoločnosti, musí cielene usmerňovat' trajektóriu takéhoto rozvoja spoločensky legitímnym smerom. Ústava ho nemôže brzdit', ani byt' mimo neho, inak stratí materiálnu legitimitu.

Ústavný systém SR je aj po takmer 30 rokoch vývoja v pohybe. Kl'účovým motorom tohto pohybu sú iba výnimočne vonkajšie, zahraničné faktory. Tým kl'účovým hnacím motorom je neustála vnútorná dynamika ústavného systému, ktorý sa stále formuje. Ústavný systém aj po skoro 30 rokoch vykazuje dynamické prvky meniace v čase vnútorné vzt'ahy, pričom možno nadobudnút' pocit, že táto dynamika je sama osebe ciel'om. Inak povedané, nebadat' jasnú a zretel'nú trajektóriu vývoja ústavného systému s jasne a spoločensky konsenzuálne akceptovaným ciel'om, ku ktorému by tento systém, či už rozhodovacou činnost'ou ústavných orgánov alebo formovaním a kultivovaním nepísaných pravidiel, smeroval.

Na túto dynamiku ústavného systému pozerám optikou dvoch ústavných orgánov, a to Národnej rady SR a Ústavného súdu SR. Národná rada SR je v udržiavaní dynamiky a napätia v ústavnom systéme SR rozhodujúcim hráčom. Jej postavenie ako jediného ústavodarného orgánu vytvára predpoklad na systematické formovanie ústavného systému v medziach daných ústavou $\mathrm{v}$ dvoch úrovniach (i) vnútornej, čím chápem postavenie, úlohy a význam samotnej Národnej rady SR v ústavnom systéme, a (ii) vonkajšej, čím chápem utváranie a formovanie vzt’ahov jednotlivých ústavných orgánov v ústavnom systéme.

V tejto vonkajšej úrovni ústavodarnej činnosti by malo platit', že konanie Národnej rady SR ako jediného ústavodarného orgánu je založené na tom, že existuje (či už od

\footnotetext{
${ }^{8}$ Základný argument proti materiálnemu jadru ústavy spočívajúci $\mathrm{v}$ jeho neuchopitel’nosti - napr. PROCHÁZKA, R. Lud a sudcovia v konštitučnej demokracii. Plzeň : Aleš Čeněk, 2011, s. 31 a nasl. - bol redukovaný ústavoochrannou činnost'ou Ústavného súdu SR vo veciach PL. ÚS 21/2014 a PL. ÚS 7/2017.

${ }^{9}$ Ústavný zákon č. 71/2017 Z. z.
} 
vzniku SR, ale aspoň počas jej doterajšej existencie) spoločensky akceptovaná nadpolitická vízia či predstava toho, ako má byt ústavný systém usporiadaný tak, aby spoločenstvo osôb v ňom mohlo prežívat' plnohodnotný a dôstojný život. Táto vízia by mala byt' napíňaná a chránená systematickými rozhodnutiami jediného ústavodarného orgánu, a to nezávisle od momentálnej ústavodarnej generácie.

Z hl'adiska vlastného vnútorného miesta Národnej rady SR v ústavnom systéme a jeho formovania je prístup Národnej rady SR ako jediného ústavodarného orgánu prinajmenšom ambivalentný. Zastávam názor, že žiadna zmena ústavy týkajúca sa postavenia Národnej rady SR ako ústavodarného orgánu nebola výsledkom strategického rozhodnutia o jej mieste v dlhodobej, nadgeneračnej vízii vývoja slovenskej spoločnosti. Aj bez takejto ambície by malo byt' možné identifikovat' aspoň to, či je ciel'om Národnej rady SR svojou vlastnou ústavodarnou činnost'ou svoje miesto v ústavnom systéme (i) posilňovat' tým, že by si vyhradila konečné rozhodnutie v zásadných otázkach existencie a rozvoja ústavného rámca života spoločenstva alebo (ii) oslabovat' zužovaním takýchto rozhodnutí a ich presunom napr. na občanov.

Pokúsim sa predstavit’ svoj názor na tom, že výsledkom 28-ročnej ústavodarnej činnosti Národnej rady SR týkajúcej sa samej seba nie je ani jedno, ani druhé. Výsledkom je stav živelného a nesystémového vytvárania postavenia jediného ústavodarného orgánu rámcovaného (i) nominálne impozantným rozsahom rozhodnutí s požiadavkou ústavnej väčšiny, ktoré sú však obsahovo v mnohých prípadoch pre ústavný systém bezvýznamné, (ii) postupným prelamovaním konečnosti rozhodnutí prijatých ústavnou väčšinou, ale tiež (iii) omylnost’ou jediného ústavodarného orgánu a (iv) zneužívaním postavenia ústavodarného orgánu.

\section{(i) rozsah rozhodnutí s požiadavkou ústavnej väčšiny}

Národná rada SR rozhodujúca požadovanou ústavnou väčšinou ${ }^{10}$ je v ústavnom systéme všemocná. Národná rada SR môže zmenit’ štátne hranice, môže rozhodnút' o vypovedaní vojny inému štátu, môže zrušit' amnestiu alebo milost'. Národná rada SR je silnejšia ako občania, pretože môže zmenit' alebo zrušit’ platný výsledok referenda, môže zasahovat' do ústavnej úpravy základných práv a slobôd ${ }^{11}$ a aj ich zrušit', pretože ústavný zákaz ich zrušenia pre neho neplatí. ${ }^{12}$ Národná rada SR môže rozhodnút' o strate mandátu poslanca Národnej rady SR získaného vo vol'bách. ${ }^{13}$

Kým v roku 1992 bola potreba súhlasu aspoň 3/5 väčšiny všetkých poslancov Národnej rady SR rámcovaná:

${ }^{10}$ Ústavná väčšina je to jediné, čo odlišuje Národnú radu SR konajúcu ako zákonodarný orgán a Národnú radu SR konajúcu ako ústavodarný orgán, preto je tomuto jedinému odlišujúcemu prvku potrebné venovat' pozornost'.

${ }^{11} \mathrm{~K}$ tomu SVÁK, J. - BALOG, B. Pokusy o ústavné zmeny v oblasti l'udských práv a realita. In 20 rokov Ústavy Slovenskej republiky. Košice : Univerzita Pavla Jozefa Šafárika v Košiciach, Právnická fakulta, 2012, s. $148-154$.

${ }^{12}$ FRIDRICH, B. a kol. Ústavné garancie l’udských práv. Bratislava : PraF UK, 2013, s. 31.

${ }^{13}$ Čl. 10 ods. 1 ústavného zákona č. 357/2004 Z. z. o ochrane verejného záujmu pri výkone funkcií verejných funkcionárov. 
- prijatím ústavy,

- zmenou ústavy,

- prijatím ústavného zákona,

- zmenou ústavného zákona,

- vol'bou a odvolaním prezidenta a

- vypovedaním vojny inému štátu; ${ }^{14}$

tak od 1. januára 2021 je to už:

- prijatím ústavy,

- zmenou ústavy, ${ }^{15}$

- prijatím ústavného zákona,

- zmenou ústavného zákona,

- vyslovením súhlasu s medzinárodnou zmluvou podla čl. 7 ods. 2 Ústavy SR,

- prijatím uznesenia o l’udovom hlasovaní o odvolaní prezidenta Slovenskej republiky,

- podaním obžaloby na prezidenta,

- vypovedaním vojny inému štátu,

- zrušením rozhodnutia prezidenta podl'a čl. 102 ods. 1 písm. j) Ústavy SR a

- vol'bou kandidáta na sudcu Ústavného súdu SR.

Rozsah právomocí Národnej rady SR vykonávaných ústavnou väčšinou tým nie je vyčerpaný, pretože tento sa rozšije polylegálnou ústavou aj o:

- rozhodovanie podl’a čl. 10 ods. 1 ústavného zákona č. 357/2004 Z. z. o ochrane verejného záujmu pri výkone funkcií verejných funkcionárov a

- vol'bu a odvolanie predsedu Rady pre rozpočtovú zodpovednost'.

Sila Národnej rady SR je daná aj tým, že ústavnou väčšinou zriad'uje, ruší a mení ústavné orgány. $Z$ jej dosahu nie je vylúčený ani jeden. Národná rada SR ústavné orgány vytvára, a to nielen v unikátnom momente vzniku štátu a prvotného formovania ústavného systému, ale aj počas jeho existencie. Národná rada SR mení ich postavenie, kompetencie, spôsob ich kreovania, a tým aj vzt’ahy medzi nimi. Tým ovplyvňuje a formuje aj vnútorné vzt’ahy v ústavnom systéme.

Štruktúru ústavných orgánov vytvorenú a založenú v momente vzniku štátu nepokladám za konečnú a nedotknutel'nú, ale aj tu platí, že zásah do nej môže byt' výsledkom systematického formovania tejto štruktúry s daným a spoločensky akceptovaným ciel'om konečnej štruktúry ústavného systému, alebo takýto zásah môže byt' výsledkom momentálneho rozhodnutia ústavodarnej generácie bez širších a hlbších spoločenských súvislostí. ${ }^{16}$

${ }^{14}$ Čl. 84 ods. 3 Ústavy SR v schválenom znení. Okrem toho sa vyžadovala ústavná väčšina aj na prijatie uznesenia Národnej rady SR podl’a čl. 10 ods. 2 ústavného zákona č. 119/1995 Z. z. o zamedzení rozporu záujmov pri výkone funkcií ústavných činitel'ov a vyšších štátnych funkcionárov.

${ }^{15}$ Napriek opakovanému zásahu do čl. 84 ústavy, Národná rada SR tam doteraz ponechala slová „zmenu ústavy“ bez úpravy toho, čo je to vlastne formálne a obsahovo zmena ústavy a aký je rozdiel oproti ,prijatie ústavy“. Odpoved’ však ponúka M. Breichová Lapčáková v tom, že tento rozdiel musí byt' obsahový, resp. materiálny - BREICHOVÁ LAPČÁKOVÁ, M. Nezrušitelné ústavné princípy vo viacúrovňovom právnom systéme. Košice : Univerzita Pavla Jozefa Šafárika, 2020, s. 69.

${ }^{16} \mathrm{~V}$ d'alšom texte $\mathrm{k}$ téme chybovosti Národnej rady SR poukážem na jej trápenie práve v kreačnej oblasti. Ako exemplárny príklad absolútne nesystémového prístupu k formovaniu ústavného systému môže slúžit' snaha zásadne vecne zmenit’ Prokuratúru SR v ústave pozmeňujúcim návrhom. Nakoniec to nebola úspešná snaha. 
Od roku 1993 dochádza k nominálnemu rozširovaniu právomocí Národnej rady SR vykonávaných ústavnou väčšinou, čím by sa jej váha v ústavnom systéme mala materiálne zvyšovat', ale podl’a mňa to tak nie je. Výsledkom je iba inflácia ústavnej väčšiny. Narastanie prípadov, ked' sa na rozhodnutie vyžaduje ústavná väčšina, znamená, že toto rozhodnutie a s ním spojená väčšina už nie sú exkluzívne vyhradené pre zásadné, najdôležitejšie otázky života a vývoja štátu a spoločenstva, o ktorých by mal rozhodovat' parlament ako ústavný orgán s priamou demokratickou legitimitou. Tento si na seba zmenami ústavy ako jediný ústavodarný orgán naviazal právomoci vykonávané ústavnou väčšinou, čím ju fakticky zdevalvoval.

\section{(ii) prelamovanie konečnosti rozhodnutí prijatých ústavnou väčšinou}

Okrem inflácie ústavodarnej väčšiny pri rozhodovaní sme svedkami paralelného javu, a to jej relativizácie. Pod relativizáciou ústavnej väčšiny rozumiem jav, ked' rozhodnutie, na ktoré sa vyžaduje ústavná väčšina, nie je konečné, ale podlieha d’alšiemu schval'ovaniu, osobitne ak ide o d'alšie schval'ovanie v inštitucionálnom prostredí. Tým sa význam ústavnej väčšiny znižuje.

Ústava z roku 1992 poznala iba jednu situáciu, ked' rozhodnutie Národnej rady SR schval'ované vyžadovanou ústavnou väčšinou nebolo konečné, a to vstup do štátneho zväzku s iným štátom alebo vystúpenie z neho. Vstup do štátneho zväzku s iným štátom by znamenal zánik samostatnej Slovenskej republiky. Pokladám preto za prirodzené, že ústava od roku 1992 na takéto rozhodnutie vyžaduje referendum. Referendum nasleduje po ústavnom zákone o vstupe do štátneho zväzku s inými štátmi. Bez takéhoto ústavného zákona sa referendum $\mathrm{v}$ tejto veci konat' nemôže a súčasne ide o referendum ratifikačné, bez platného výsledku, ktorého účinky ústavného zákona nenastanú. Vôla Národnej rady SR zrušit' samostatnú Slovenskú republiku, aj ked' vyjadrená ústavnou väčšinou, nie je konečná a podlieha priamej moci občanov vyjadrenej v referende. Či všeobecnejšie: najvyššia ustanovená moc môže byt' prekonaná iba mocou ustanovujúcou. ${ }^{17}$

Priama vol'ba prezidenta zasiahla aj do postavenia Národnej rady SR konajúcej ústavnou väčšinou. Tá už o prezidentovi nerozhodovala, ale svoje miesto si našla pri ukončovaní výkonu funkcie prezidenta počas jeho volebného obdobia. Priamo volený prezident je odvolatel'ný iba občanmi v l’udovom hlasovaní. Národná rada SR si výlučne vyhradila iniciovanie takéhoto l'udového hlasovania. Nie je mi známe, či predmetom úvah v roku 1999 bola aj alternatíva, že by iniciátorom l'udového hlasovania boli priamo občania petíciou, na ktorej základe by predseda Národnej rady SR l'udové hlasovanie vyhlásil. Ak ale Národná rada SR v roku 1999 rozhodla, že iniciovanie l’udového hlasovania má byt' v inštitucionálnom prostredí ústavných orgánov a konkrétne ho zverila sebe, je to možné vnímat' kladne v rozsahu, že na prijatie rozhodnutia ústavnou väčšinou je potrebná širšia zhoda a integrácia politických síl v Národnej rade SR.

Schválená konštrukcia iniciovania l'udového hlasovania priniesla d’alší prvok, v ktorom rozhodnutie Národnej rady SR prijaté ústavnou väčšinou nie je konečné. V tejto

\footnotetext{
${ }^{17}$ Prirodzenou ústavnou koncovkou by malo byt' povinné rozpustenie Národnej rady SR, ak by referendum nebolo úspešné, alebo ak by občania rozhodli inak ako Národná rada SR ústavným zákonom.
} 
konštrukcii rozhodujú s konečnou platnost'ou občania v l'udovom hlasovaní (s fatálnymi účinkami či pre prezidenta, alebo Národnú radu SR). Podstata pôvodnej konštrukcie ústavy, že ústavná väčšina je prekonaná občanmi, však zostala zachovaná.

Ústava v roku 1999 priniesla aj modifikáciu pôvodnej úpravy obžaloby prezidenta a stanovila, že konanie na Ústavnom súde SR sa začína na návrh Národnej rady SR, ktorá sa na podaní obžaloby uznáša ústavnou väčšinou. Tým bola v ústave založená výslovná konštrukcia, v ktorej rozhodnutie Národnej rady SR prijaté ústavnou väčšinou nebolo ani konečné a ani nepodliehalo ratifikácii mocou ustanovujúcou, ale rozhodnutie (aj ked' nie vo veci, ale len o podaní obžaloby, v podstate návrh na začatie konania) prijaté ústavnou väčšinou podliehalo konečnému rozhodnutiu iného ústavného orgánu.

Ústavným zákonom č. 71/2017 Z. z. si Národná rada SR v čl. 86 písm. i) zverila právomoc „uznášat’ sa o zrušení rozhodnutia prezidenta podl'a čl. 102 ods. 1 pism.j), ak odporuje princípom demokratického a právneho štátu; prijaté uznesenie je všeobecne záväzné a vyhlasuje sa rovnako ako zákon". Národná rada SR sa uznáša ústavnou väčšinou a jej uznesenie, ktoré je rozhodnutie o zrušení rozhodnutia prezidenta, nie iba návrh na začatie konania, podlieha preskúmaniu Ústavným súdom SR. Zásadný posun oproti obžalobe prezidenta je práve v tom, že uznesenie Národnej rady SR o zrušení rozhodnutia prezidenta podl'a čl. 102 ods. 1 písm. j) ústavy nie je návrh na začatie konania pred Ústavným súdom SR, ale je to rozhodnutie vo veci. Okrem tohto momentu však ústavný zákon č. 71/2017 Z. z. vniesol do postavenia Národnej rady SR konajúcej požadovanou ústavnou väčšinou zásadný prvok - prvýkrát ustanovil referenčný základ preskúmania jej rozhodnutia.

Kým v prípade referenda o vstupe do štátneho zväzku ide o politické rozhodnutie, rovnako ako aj v prípade l'udového hlasovania o odvolaní prezidenta, a kým v prípade obžaloby prezidenta ide iba o návrh na začatie konania, v prípade rozhodnutia o zrušení amnestie alebo milosti ide o rozhodnutie, ktoré Ústavný súd SR preskúmava s jasne stanoveným referenčným základom, ktorým je súlad s ústavou v rozsahu princípov demokratického a právneho štátu. Tým bol do relativizácie ústavnej väčšiny vnesený prvok, ktorý v čl. 7 alebo v čl. 106 a 107 prítomný nebol - preskúmanie rozhodnutia prijatého ústavnou väčšinou $\mathrm{z}$ dôvodu nesúladu s ústavou.

Inak povedané, Národná rada SR konajúca ako jediný ústavodarný orgán prijala takú zmenu ústavy, ktorou sama pripustila, že ňou samou prijaté rozhodnutie ústavnou väčšinou nielenže nie je konečné, ale toto rozhodnutie môže byt' nesúladné s ústavou.

Nakoniec je možné uviest’ ústavný zákon č. 422/2020 Z. z., ktorý požiadavku ústavnej väčšiny rozšíril aj na vol'bu kandidátov na sudcov Ústavného súdu SR. Kandidát potrebuje presvedčit' Národnú radu SR v rozsahu ústavnej väčšiny. Ani to však z neho sudcu Ústavného súdu SR neurobí, pretože konštrukcia ich menovania prezidentom z dvojnásobného počtu kandidátov zostala zachovaná. Požiadavka ústavnej väčšiny na vol'bu kandidáta na sudcu Ústavného súdu SR v spojení s novou možnostou prezidenta vymenovat' sudcov Ústavného súdu SR aj z neúplného počtu zvolených kandidátov, ak Národná rada SR nezvolí potrebný počet kandidátov do dvoch mesiacov od uplynutia funkčného obdobia alebo do šiestich mesiacov od zániku funkcie sudcu Ústavného súdu 
SR, vytvára stav potenciálneho posilnenia prezidenta na úkor Národnej rady SR konajúcej ústavnou väčšinou. Nehodnotím túto konštrukciu z hl'adiska vhodnosti alebo nevhodnosti na vytváranie personálneho základu nezávislého súdneho orgánu ochrany ústavnosti, ale hodnotím ju z hl’adiska miesta ústavnej väčšiny v nej. Domnievam sa, že nominálne rozšírenie ústavnej väčšiny v prípade kandidátov na sudcov Ústavného súdu SR povedie fakticky $\mathrm{k}$ oslabeniu váhy tejto väčšiny a $\mathrm{k}$ jej d’alšej relativizácii.

\section{(iii) omylnost' jediného ústavodarného orgánu}

Národná rada SR konajúca ústavnou väčšinou nie je neomylná, aj ked' spojenie minimálne 90 poslancov do ústavodarnej generácie predpokladá vnútornú diskusiu a hladanie najlepšieho riešenia.

Zmena ústavy, aj rigidnej, je legitímna, ak je výsledkom uváženého, premysleného vecne správneho a spoločensky akceptovaného rozhodnutia reagujúceho na vnútorný alebo zahraničný podnet. Takéto rozhodnutie sa časom môže zmenit' a prehodnotit' tak, ako sa vyvíja život spoločenstva. Takúto situáciu, na ktorú reaguje ústavodarca, nevnímam ako jeho omyl, a to ani vtedy, ak je predmetom opakovanej ústavnej zmeny ten istý ústavný inštitút, či dokonca ich celok. Takto hodnotím napríklad redefiníciu Súdnej rady SR v dokopy už tret’om znení čl. 141a ústavy ${ }^{18}$ od jeho prijatia v roku 2001. To, že Národná rada SR za 20 rokov už dvakrát pristúpila k úplnej zmene čl. 141a ústavy, nehodnotím ako jej neschopnost' vysporiadat' sa so Súdnou radou SR a jej miestom v ústavnom systéme SR, ${ }^{19}$ ale ako hl'adanie jej vhodného miesta v tomto systéme.

O omylnosti ústavodarcu hovorím vtedy, ak k zmenám ústavy dochádza náhodne, až chaoticky, zjavne bez hlbšie zanalyzovaného dôvodu a bez riadnej legislatívnej prípravy. Za notorický príklad takéhoto prístupu pokladám úpravu poslaneckej imunity, ktorá za 20 prekonala búrlivejší vývoj ako Súdna rada SR. K zmene či zásahu do poslaneckej imunity pristupovala Národná rada SR v rokoch 1992 až 2012 opakovane, pričom jed-

\footnotetext{
${ }^{18}$ Prvá úprava v ústavnom zákone č. 90/2001 Z. z., druhá v ústavnom zákone č. 161/2014 a napokon súčasná v ústavnom zákone č. 422/2020 Z. z. účinná od 1. januára 2021.

${ }^{19}$ Dlho išlo o doménu Ústavného súdu SR - v náleze sp. zn. PL. ÚS 2/2012 uviedol: „Doterajšia judikatúra ústavného súdu Súdnu radu Slovenskej republiky ústavnoprávne charakterizovala ako osobitný sui generis samosprávny ústavný orgán (I. ÚS 62/06, s. 8; I. ÚS 162/09, s. 14; II. ÚS 29/2011, s.11; PL. ÚS 102/2011, s.121) súdnej moci (PL. ÚS 10/05, s. 86), ktorý je najvyššim orgánom súdnej moci (PL. ÚS 102/2001, s. 134; m. m. IV. ÚS 46/2011, s. 12; m. m. I. ÚS 454/2012, s. 18), pričom jedným z jeho základných inštitucionálnych prvkov je nezávislost' (IV. ÚS 46/2011, s. 12), predovšetkým:

- zabezpečuje nezávislé postavenie súdnej moci vo vzt’ahu k iným orgánom štátu (III. ÚS 79/04, s. 8; III. ÚS 238/05, s. 9; III. ÚS 128/09, s. 13), resp. jej pôsobnost'slúži na vytvorenie mechanizmu zaručujúceho nezávislost' súdnej moci od moci výkonnej (PL. ÚS 17/08, s. 100), resp. je „garantom“ nezávislosti súdnictva a jeho oddelenia od ostatných orgánov štátu (PL. ÚS 10/05, s. 89);

- zodpovedá za chod súdnictva (PL. ÚS 102/2011, s. 121);

- zabezpečuje sudcovskú legitimitu (PL. ÚS 102/2011, s. 134);

- vykonáva správu súdnej moci, t.j. rozhoduje alebo spolurozhoduje alebo sa vyjadruje kotázkam ekonomického, finančného, organizačného a personálneho zabezpečenia výkonu súdnej moci a sčasti aj jeho kontroly (PL. ÚS 10/05, s. 56; PL. ÚS 102/2011, s. 145);

- pôsobi pri správe súdnictva v súčinnosti s ministerstvom spravodlivosti alebo ministrom spravodlivosti (PL. ÚS 10/05, s. 56);

- zodpovedá za transparentnost' súdnictva (PL. ÚS 102/2011, s. 134).“
} 
notlivé zásahy nie je možné pokladat' za výsledok hlbšieho a dôkladnejšieho vecného premyslenia, ani riadnej legislatívnej prípravy a už vôbec nie spoločenskej požiadavky, v tomto poslednom práve naopak. Ku cti jej slúži, že napokon v roku 2012 prestala hl'adat' všelijaké skratkovité riešenia výhodné pre seba samu, ale na základe spoločenskej požiadavky výrazne poslaneckú imunitu (sama sebe) zúžila, a tým svoje trápenie ukončila.

K téme omylnosti Národnej rady SR ešte jeden menej známy príklad z roku 2019. Národná rada SR v tomto roku podl'a mňa vytvorila svoj vlastný rekord v neschopnosti. Netýkal sa ústavy, ale ústavného zákona č. 357/2004 Z. z. o ochrane verejného záujmu pri výkone funkcií verejných funkcionárov. Národná rada SR dokázala tento ústavný zákon v roku 2019 novelizovat' trikrát, z toho raz dokonca v skrátenom legislatívnom konaní. Aby toto ešte nestačilo, dôvod, pre ktorý hovorím o neschopnosti Národnej rady $\mathrm{SR}$, je, že predmetom všetkých troch zmien bolo v podstate stále jedno a to isté ustanovenie v čl. 2 písm. zc) tohto ústavného zákona.

Národná rada SR pri zmenách tohto ustanovenia vychádzala zo spoločensky oprávnenej a legitímnej požiadavky, aby sa ochrana verejného záujmu nevzt'ahovala iba na zástupcov štátu v štatutárnych orgánoch obchodných spoločností so stopercentnou majetkovou účast'ou štátu, ale aby vzt'ahovala aj na tie osoby, ktoré zastupujú štát v spoločnostiach s väčšinovou majetkovou účast’ou štátu a ich dcérskych spoločnostiach.

Národná rada SR vedená takouto úžasnou myšlienkou pristúpila bez nejakého náročnejšieho uvažovania o jej obsahu a dosahu a bez nejakej náročnejšej legislatívnej prípravy hned' k realizácii. Ústavným zákonom č. 66/2019 Z. z. z 31. januára 2019 účinným od 1. januára 2020 ustanovila, že tento ústavný zákon sa vzt’ahuje aj na štatutárny orgán alebo členov štatutárneho orgánu a členov dozorných rád právnických osôb, v ktorých má majoritnú majetkovú účast’ štát vrátane ich dcérskych spoločností. Ak by Národná rada SR príprave legislatívneho riešenia svojej úžasnej myšlienky venovala aspoň trochu pozornosti, neuniklo by jej, že členmi štatutárneho orgánu a dozornej rady v právnickej osobe, v ktorej má majoritnú účast' štát, nie sú iba zástupcovia štátu, ale aj zástupcovia toho, kto má v takejto právnickej osobe minoritnú účast', napr. súkromný investor. A presadzovanie verejného záujmu od jeho zástupcov nemožno spravodlivo očakávat'.

Národná rada SR svoju chybu uznala a ústavným zákonom č. 232/2019 Z. z. z 26. júna 2019 účinným od 1. januára 2020 zmenila čl. 2 písm. zc) tak, že sa vzt’ahuje na štatutárny orgán alebo členov štatutárneho orgánu a členov dozorných rád právnických osôb, ktorých do funkcie navrhuje alebo ustanovuje štát alebo právnická osoba, v ktorej má majoritnú majetkovú účast' štát. Ani toto riešenie sa neukázalo ako dostatočné. Dôvodom bola skutočnost', že nie každý zástupca štátu je navrhnutý alebo ustanovený štátom priamo, ale jeho nominácia môže byt' výsledkom postupných úkonov, napr. v holdingovej spoločnosti. Ak by Národná rada SR myšlienke o rozšírení pôsobnosti ústavného zákona č. 357/2004 Z. z. venovala náležitú pozornost', tak by takéto situácie musela identifikovat'. Nedostatok rozumu však vyvažuje húževnatost'.

A tak 5. decembra 2019 Národná rada SR v skrátenom legislatívnom konaní (!) schválila ústavný zákona č. 469/2019 Z. z. s účinnost’ou od 1. januára 2020, ktorým 
ustálila čl. 2 písm. zc) tak, že sa vzt’ahuje na štatutárny orgán alebo členov štatutárneho orgánu, členov riadiaceho orgánu a členov kontrolného orgánu alebo dozorného orgánu právnických osôb, ktorých do funkcie priamo alebo nepriamo navrhuje alebo ustanovuje štát alebo právnická osoba so stopercentnou majetkovou účast'ou štátu.

\section{(iv) zneuživanie postavenie jediného ústavodarného orgánu}

Osobitným spôsobom, ktorým Národná rad SR demonštruje svoju všemocnost', je prelamovanie rozhodnutí Ústavného súdu SR, ktoré zarad’ujem do skupiny zneužívania postavenia jediného ústavodarného orgánu. Úmyselne použité slovo „prelamovanie“ naznačuje nelichotivé konotácie takéhoto konania. Nejde o akúkol'vek reakciu parlamentu na rozhodnutie orgánu ochrany ústavnosti. Ústavodarná reakcia na rozhodnutie orgánu ochrany ústavnosti je nielen legitímna, ale v mnohých prípadoch aj potrebná, a nahrádza chýbajúcu pozitívnu ústavotvornú schopnost' orgánu ochrany ústavnosti, ktorý ňou pre nedostatok legitimity nedisponuje.

Prelamovanie rozhodnutí orgánu ochrany ústavnosti parlamentom predstavuje to, ked' parlament v snahe presadit' svoju predstavu o úprave spoločenských vzt'ahov zmení ústavu obsahovo v rozpore s rozhodnutím orgánu ochrany ústavnosti. Národná rada SR ukázala, že s takýmto použitím svojej ústavodarnej moci nemá problém:

1. Dnes už legendárnym je ústavný zákon č. 254/2006 Z. z. o zriadení a činnosti výboru Národnej rady Slovenskej republiky na preskúmavanie rozhodnutí Národného bezpečnostného úradu. Tomuto ústavnému zákonu bola v odbornej literatúre venovaná rozsiahla pozornost' a podnietil aj mnoho skvelých príspevkov, čo bola asi jeho jediná svetlá stránka. ${ }^{20}$

Napriek tomu, že Ústavný súd SR v náleze sp. zn. PL. ÚS 6/04 rozhodol, že ustanovenie $\S 30$ ods. 4 až 7 zákona č. 215/2004 Z. z. o ochrane utajovaných skutočností a o zmene a doplnení niektorých zákonov nie je v súlade s čl. 1 ods. 1 prvou vetou, čl. 2 ods. 2 a s čl. 46 ods. 1 ústavy, vôl'a Národnej rady SR preskúmavat' cez svoj osobitný výbor rozhodnutia Národného bezpečnostného úradu ${ }^{21}$ bola silnejšia ako ochrana ústavnosti.

Aj po rokoch stojí za to pripomenút' si v tejto súvislosti názor prof. A. Bröstla, ktorý okrem kritiky postupu Národnej rady SR začal hovorit' aj o téme ústavnosti ústavných zákonov. ${ }^{22}$ Prof. A. Bröstl pred dvanástimi rokmi a bez možnosti poznat', ako sa Národná

${ }^{20}$ NIKODÝM, D. Kompatibilita ústavného systému. In Právny obzor, 90, 2007, č. 5; VOZÁR, J. Súd locuta kauza finita (niekol'ko poznámok k prijatému ústavnému zákonu č. 254/2006 Z. z.). In Právny obzor, 2006, č. 3; BRÖSTL, A. O ústavnosti ústavných zákonov. In JERMANOVÁ, H. - MASOPUST, Z. (eds.) Metamorfózy práva ve středni Evropě. Praha : Ústav státu a práva, 2008; BALOG, B. Ústavné zákony v právnom poriadku Slovenskej republiky. In Justičná revue, roč. 59, č. 12, 2007, s. 1584; SVÁK, J. CIBULKA, L. - KLÍMA, K. Ústavné právo Slovenskej republiky. Všeobecná čast'. Bratislava : Bratislavská vysoká škola práva, 2008, s. 153.

${ }^{21}$ Či skôr dostat' sa k utajovaným informáciám z jeho spisov?

${ }^{22}$ BRÖSTL, A.: O ústavnosti ústavných zákonov. In: JERMANOVÁ, H. - MASOPUST, Z. (eds.): Metamorfózy práva ve strední Evropě. Praha : Ústav státu a práva, 2008. Ďalej potom $\mathrm{k}$ tejto téme aj BREICHOVÁ LAPČÁKOVÁ, M. Neústavné ústavné zákony? II. čast'. In Justičná revue, 2011, roč. 63, č. 2; BALOG, B. Neústavný ústavný zákon - na príklade priestupkovej imunity poslancov parlamentu na Slovensku. In JIRÁSEK, J. (ed.) Ústava ve stínu politiky? Olomouc : Iuridicum Olomoucense, 2012, $390 \mathrm{~s}$. 
rada SR k svojej ústavodarnej právomoci postaví do budúcna, kriticky vyslovil, že „Ústavné zákony, ktoré ústava nepredpokladá (kvázi ústavné zákony) doposial nepôsobili rušivo (okrem ústavného zákona o skrátení volebného obdobia), až pokial' nedošlo na prelamovanie rozhodnutí ústavného súdu. Argumentácia v prospech takých ústavných zákonov vychádza z absolutizácie ústavodarnej právomoci: národná rada jednoducho dostala do vienka ústavodarnú právomoc a záleži iba od nej, ako a kedy ju využije. Rozumej: každý ústavný zákon je realizáciou tejto právomoci. Pritom sa vychádza z d'alšej axiómy, že ústavný súd nemá právomoc posudzovat súlad ústavných zákonov s ústavou, pretože ide o dva pramene ústavného práva, ktoré majú rovnaký stupeñ právnej sily adodávam - nemôže byt' medzi nimi rozpor." ${ }^{\text {23 }}$ Táto kritika potom smerom k ústavnému zákonu č. 254/2006 Z. z. viedla k záveru, že ,...ide o protiústavný ústavný zákon, a to hned'z niekol'kých pohl'adov: nie je výsledkom ústavodarnej právomoci národnej rady, nerešpektuje rozhodnutie (nález) Ústavného súdu..." a vo vzt'ahu k Národnej rade SR, že „Nepredpokladá sa, že národná rada v rámci realizácie a pokračovania konania o súlade bude reagovat' na nesúladný zákon nesúladným ústavným zákonom. “24

2. Medzi ústavné zákony prelamujúce rozhodnutie Ústavného súdu SR zarad’ujem aj ústavný zákon č. 161/2014 Z. z. Národná rada SR sa ústavným zákonom č. 161/2014 Z. z. pokúsila obíst' protiústavné prvky v účasti Národného bezpečnostného úradu na kreácii a fungovaní súdnej moci tak, že právnu úpravu pôsobenia a vplyvu tohto subjektu (s eufemistickým označením v ústave) na súdnu moc v štádiu preverovania kandidátov na sudcov povýšila zo zákona na ústavný zákon.

Národná rada SR sa svojej predstavy o previerkach sudcov cez NBÚ vzdat' nechcela a súčasne ani nebola schopná iného mentálneho výkonu v tejto veci, iba toho, s ktorým v pozícii zákonodarcu na Ústavnom súde SR neuspela. Previerky ustanovené zákonom č. 458/2003 Z. z. o zriadení Špeciálneho súdu a Úradu špeciálnej prokuratúry a o zmene a doplnení niektorých zákonov v znení neskorších predpisov, ktoré pred Ústavným súdom SR neobstáli, sa v mierne prikrášlenej, ale vecne fakticky rovnakej úprave, ocitli prostredníctvom ústavného zákona č. 161/2014 Z. z. priamo v ústave.

Z formálneho hladiska bol ústavný zákon č. 161/2014 Z. z. odlišný od ústavného zákona č. 254/2006 Z. z. v tom, že bol priamou novelou ústavy. Navodzoval sa tým dojem, že zásadný problém ústavného zákona č. 254/2006 Z. z., teda to, že išlo o účelový ústavný zákon, prijatie ktorého ústava nepredpokladá, v prípade ústavného zákona č. 161/2014 Z. z. neexistuje. Pripustenie existencie protiústavného zákona sa totiž vytesnilo do sféry tých ústavných zákonov, ktoré sú v polylegálnej ústave mimo jej vlastného textu, resp. mimo ústavného zákona č. 460/1992 Zb. ${ }^{25}$ Tento predpoklad sa ukázal ako klamlivý.

${ }^{23}$ BRÖSTL, A. O ústavnosti ústavných zákonov. In JERMANOVÁ, H. - MASOPUST, Z. (eds.) Metamorfózy práva ve střední Evropě. Praha : Ústav státu a práva, 2008, s. 23.

${ }^{24}$ BRÖSTL, A. O ústavnosti ústavných zákonov. In JERMANOVÁ, H. - MASOPUST, Z. (eds.) Metamorfózy práva ve středni Evropě. Praha : Ústav státu a práva, 2008, s. 18.

${ }_{25}$ To, že by malo íst' iba o problém účelových ústavných zákonov, bolo posilnené v roku 2009 aj rozhodnutím Ústavného súdu ČR v náleze sp. zn. Pl. ÚS 27/2009 v známej veci „Melčák“. 


\section{Právomoc Ústavného súdu SR}

Ústavný súd SR právomocou rozhodovat' o súlade ústavného zákona s ústavou nikdy nedisponoval. Ústavodarca mu ju nikdy výslovne v ústave nepriznal a domnievam sa, že by ňou v demokratickom a právnom štáte ani disponovat' nemal. Za základný stavebný princíp ústavného systému SR pokladám princíp suverenity l'udu, ktorý sa pretavuje do postavenia Národnej rady SR ako jediného zákonodarného a ústavodarného orgánu SR, ktorý disponuje nielen legislatívnou právomocou, ale nesie aj zodpovednost' za stav právneho poriadku SR.

Ústavný súd SR právomocou rozhodovat' o súlade ústavného zákona s ústavou nedisponuje ani implicitne. Takúto právomoc sám pre seba nevyvodil ani v náleze sp. zn. PL. ÚS 21/2014 a ani sa nedomnievam, že by to bolo jeho ciel'om.

Ak malo byt' doplnenie čl. 125 ods. 4 ústavy reakciou na nález sp. zn. PL. ÚS 21/2014, tak Národná rada SR nepochopila úplnú podstatu tohto nálezu.

Predpokladal som, že v roku 2020 bude v spoločnosti zhoda na tom, že ústava má materiálne jadro. Pri plnom rešpekte k tomu, že predstava každého o jeho obsahu a rozsahu môže byt' rozdielna, predpokladal som zhodu aspoň na tom, že ústava nie je bezhodnotová a že má jadro tvorené princípmi demokratického a právneho štátu. Takéto materiálne jadro ústavy by však predstavovalo iba akademickú konštrukciu, ak by nebolo v ústavodarnej praxi rešpektované a ak by nebolo v ústavnoochrannej praxi chránené. $\mathrm{V}$ ústavodarnej praxi je materiálne jadro ústavy rešpektované jediným ústavodarným orgánom, ak pri prijímaní každého ústavného zákona zachováva limity stanovené týmto jadrom a v ústavnoochrannej praxi je chránené vtedy, ak existuje spôsob, ako sa vysporiadat' so situáciou, ak jediný ústavodarný orgán tieto limity pri prijímaní každého ústavného zákona nerešpektuje.

Ústavný súd SR v náleze sp. zn. PL. ÚS 21/2014 z materiálneho jadra ústavy nielenže vychádzal, ${ }^{26}$ ale poskytol mu aj ochranu. Konštatovanie jeho existencie a súčasne zistenie zásahu do neho bez toho, aby mu bola poskytnutá pred takýmto zásahom ochrana, by znamenalo zlyhanie ústavnoochrannej právomoci Ústavného súdu SR.

Ústavný súd SR preto vyslovil, že ,je oprávnený preskúmat' prípadný rozpor noriem ústavného zákona s implicitným materiálnym jadrom ústavy a ak zistí rozpor, je oprávnený vyslovit' nesúlad noriem ústavného zákona s implicitným materiálnym jadrom ústavy." Ústavný súd SR neskúmal súlad ústavného zákona s ústavou alebo iným ústavným zákonom. Predmetom jeho prieskumu bol súlad ústavného zákona s materiálnym jadrom ústavy, teda iba s tou čast’ou polylegálnej ústavy, ktorá má jadrový charakter. ${ }^{27} \mathrm{~A}$ iba $\mathrm{v}$ tomto rozsahu poskytol ochranu materiálnemu jadru, a aj to iba po naplnení podmienky mimoriadne intenzívneho zásahu do neho.

„Ústavný súd tak urobil pri plnom rešpekte k jedinému ústavodarnému orgánu Slovenskej republiky, ale tiež v snahe primät’ ho tiež k rovnakému rešpektu voči základnému

${ }^{26}$ Jeho existenciu pred tým najkomplexnejšie vyjadril v rozhodnutí o preskúmaní súladu uznesenia Národnej rady SR o zrušení rozhodnutí o amnestii a individuálnej milosti s ústavou.

${ }^{27} \mathrm{~K}$ vnútornej hierarchickej štruktúre noriem ústavy: SVÁK, J. - BALOG, B. Fragmentácia ústavy. In Zmena práva. Bratislava : SAP, 2013, s. 96-113. 
zákonu Slovenskej republiky. Inak povedané, ústavný súd takto rozhodol rešpektujúc princíp zdržanlivosti a minimálneho derogačného priestoru vo vzt'ahu $k$ ústavodarcovi, súc vedený mimoriadnou intenzitou zásahu posudzovaných ustanovení ústavy do materiálneho jadra ústavy. “28

Ústavný súd SR súčasne stanovil z jeho pohl'adu konečný a absolútny limit akéhokol'vek prieskumu ústavných zákonov: „177. Obiter dictum ústavný súd uvádza, že vyslovené právne závery o možnosti preskúmania súladu ústavného zákona (jeho časti) s ústavou sú limitované takou prípadnou úpravou ústavy, ktorá umožní originárnemu ústavodarcovi (l'udu) potvrdit' prípadnú zmenu či doplnenie ústavy v rámci ústavodarného referenda."

Nález sp. zn. PL. ÚS 21/2014 nie je možné vykladat' tak, že by ním Ústavný súd SR vyvodil svoju implicitnú právomoc rozhodovat’ o súlade ústavného zákona s ústavou bez d’alšieho. Rozhodovanie o súlade ústavného zákona s ústavou nie je možné bez toho, aby predmetom tohto prieskumu nebol mimoriadne intenzívny zásah napadnutých ustanovení ústavného zákona do materiálneho jadra ústavy. Iba v tomto rozsahu totiž existuje hierarchická štruktúra, ktorá umožňuje Ústavnému súdu SR posúdit’ napadnutú ústavnú úpravu s referenčným základom.

Z tohto pohl'adu potom to, že Ústavný súd SR po 1. januári 2021 nerozhoduje o súlade ústavného zákona s ústavou, na jeho právomoci poskytovat' ochranu materiálnemu jadru ústavy nič nemení.

\section{Záver}

K doplneniu ústavy v čl. 125 ods. 4 sa staviam kriticky najmä preto, lebo takéto doplnenie nebolo potrebné a vecne nič nevyriešilo. Formálne je v ústave vyjadrené to, čo tam vecne bolo aj pred tým.

Zmena ústavy nebola potrebná ani ako reakcia na rozhodnutie Ústavného súdu SR sp. zn. PL. ÚS 21/2014. Jeho podstata nebola v preskúmaní súladu ústavného zákona $\mathrm{s}$ ústavou. Referenčným základom na preskúmanie ústavného zákona nebola ústava ako taká, ale iba tie jej normy, ktoré vytvárajú materiálne jadro. Ústavný súd SR to aj sám vyslovil: „Ústavný zákon môže byt’v nesúlade len s niektorými normami ústavy.“

Z rozhodnutia Ústavného súdu SR sp. zn. PL. ÚS 21/2014 nie je možné vyvodit', že by jeho záujmom bolo preskúmavanie ústavnosti ústavných zákonov a zasahovanie do ústavodarnej činnosti Národnej rady SR. Nepochybujem, že Ústavný súd SR chápal svoj krok ako úplne krajný. Sám k tomu uviedol, že „Možnost’ prieskumu ústavnosti ústavných zákonov nezakladá deformáciu, aká by mala viest’ k účelovému označeniu každej zmeny ústavy za neústavnú alebo každého prijatého ústavného zákona za neústavný."

Reakcia Národnej rady SR v snahe ochránit' svoju ústavodarnú činnost’ pred Ústavným súdom SR nešla cestou preventívneho vylučovania zásahov do materiálneho jadra ústavy, čím by bola možnost' Ústavného súdu SR preskúmat' ústavný zákon vecne vylúčená, ale cestou mocenského vylúčenia (beztak neexistujúcej) právomoci.

\footnotetext{
${ }^{28}$ Nález sp. zn. PL. ÚS 21/2014.
} 
Platí, že prekročenie únosnej miery zásahu ústavného súdu do politiky môže viest' $\mathrm{k}$ tomu, že politická moc sa začne proti rozhodnutiam ústavného súdu bránit'. Výsledkom môže byt' stav ústavného chaosu, resp. až ústavnej krízy. Jedným z takýchto obranných nástrojov ústavodarcu je ,prelomenie“ rozhodnutia ústavného súdu ústavným zákonom, ako prostriedkom formálnej ústavnosti. Vážnejším obranným nástrojom ústavodarcu proti rozhodovacej činnosti ústavného súdu vo vzt'ahu k ústavným zákonom by bola taká zmena ústavy, ktorá by túto právomoc ústavného súdu výslovne regulovala, resp. by ju výslovne vylúčila. ${ }^{29}$

Výslovné vylúčenie rozhodovania o súlade ústavného zákona s ústavou však nevylučuje rozhodovanie o súlade ústavného zákona s normami ústavy, ktoré tvoria jej materiálne jadro, a to vtedy, ak by išlo o mimoriadne intenzívny zásah do neho.

Zmeny ústavy vrátane tej, ktorá sa týka čl. 125 ods. 4, môžeme hodnotit' podl'a rôznych kritérií. Môžeme ich hodnotit' o. i. aj podla toho, ako intenzívne či dokonca invazívne zasahujú do existujúcej ústavy, jej štruktúry a ústavných inštitútov, ktoré túto štruktúru vzájomnými väzbami a vzt’ahmi vytvárajú. Môžeme hovorit’ o takých zmenách ústavy, ktoré sú len technické či pracovné. Sú to zmeny, ktoré nezasahujú do štruktúry ústavy a ústavného systému a nezasahujú do ústavných inštitútov a ich ústavného usporiadania. Na základe praktických skúseností s uplatňovaním ústavy viac či menej technicky menia čast' ústavy v jej daných vecných medziach, teda intra constitutionem.

Iný charakter má ústavná zmena, ktorá ústavu vecne rozširuje. Jej existujúcu štruktúru nenarúša kvalitatívne, nezasahuje do podstaty ústavy a jej štruktúry, ale predmet ústavnej úpravy rozširuje spôsobom, ktorý pôvodnú ústavnú štruktúru vecne zachováva, ale pridáva k nej nový ústavný komponent, ktorý sa stáva jej vyváženou súčast’ou. V takom prípade už nejde o zmenu technickú, ale o rozšírenie či doplnenie ústavy o úpravu pôvodne praeter constitutionem, ktorá sa následne stáva jej nedeštruktívnou súčast'ou.

Napokon môže mat' zmena ústavy charakter nahradenia ústavy, resp. jej časti vecne novou ústavou, pri použití formálnej procedúry určenej pre zmeny danej (existujúcej) ústavy, a tým pod pláštom zmeny ústavy vytvorenie vecne novej ústavy. Z hl'adiska ústavy a jej štruktúry ide o zmenu contra constitutionem, aj ked’ sú zachované formálne „rituály“ spojené so zmenou ústavy. Takéto zmeny ústavu fakticky odstraňujú. Súčasne zakladajú ústavu novú.

Zmeny danej ústavy, ktoré fakticky túto ústavu odstraňujú a zakladajú ústavu novú, nie sú umožnené komukol'vek, a to ani ak disponuje ústavnou/ústavodarnou väčšinou. Sú vyhradené pre originálneho ústavodarcu. Tým Národná rada SR nie je. Národná rada SR ústavu nevytvorila, práve naopak, ústava vytvorila Národnú radu SR a zasadila ju do štruktúry ústavného systému ako jediný ústavodarný a zákonodarný orgán. Jej úlohou, ale aj zodpovednost'ou, je ústavu rozvíjat' a kultivovat', a tým podporovat' rozvoj spoločenstva $\mathrm{v}$ demokratickom a právnom štáte. Národná rada SR ako orgán ustanovený je viazaná materiálnym jadrom ústavy a nie je oprávnená ho odstránit', a to ani vedome a ani omylom. Ak by sa tak malo udiat' procedúrou inak určenou pre zmenu danej ústavy, musí mat' ústavný systém nástroj, ako sa bránit'. Ak tým nástrojom obrany nie je ústavo-

\footnotetext{
${ }^{29}$ BALOG, B. Materiálne jadro ústavy. Bratislava : Eurokódex, 2014, s. 124.
} 
darné referendum a ak sa nedá spoliehat' na sebaobmedzenie Národnej rady SR, tak v danej štruktúre ústavných orgánov je najprirodzenejšie očakávat' obranu materiálneho jadra ústavy od Ústavného súdu SR.

\section{Literatúra}

ALBERT, R. Constitutional Amendment and Dismemberment. In The Yale Juornal of International Law. Vol 43

BALOG, B. Ústavné zákony v právnom poriadku Slovenskej republiky. In Justičná revue, roč. 59, č. 12, 2007

BALOG, B. Neústavný ústavný zákon - na príklade priestupkovej imunity poslancov parlamentu na Slovensku. In JIRÁSEK, J. (ed.) Ústava ve stínu politiky? Olomouc : Iuridicum Olomoucense, 2012

BALOG, B. Materiálne jadro ústavy. Bratislava : Eurokódex, 2014

BREICHOVÁ LAPČÁKOVÁ, M. Neústavné ústavné zákony? II. čast'. In Justičná revue, 2011, roč. 63, č. 2

BREICHOVÁ LAPČÁKOVÁ, M. Nezrušitelné ústavné principy vo viacúrovňovom právnom systéme. Košice : Univerzita Pavla Jozefa Šafárika, 2020

BRÖSTL, A. O ústavnosti ústavných zákonov. In JERMANOVÁ, H. - MASOPUST, Z. (eds.) Metamorfózy práva ve středni Evropě. Praha : Ústav státu a práva, 2008

FRIDRICH, B. a kol. Ústavné garancie l’udských práv. Bratislava : PraF UK, 2013

GÖZLER, K. Judicial Review of Constitutional Amendments. A comparative Study. Bursa : Ekin Press

KROŠLÁK, D. - BALOG, B. - SURMAJOVÁ, Ž. Teória štátu a práva. Bratislava : Wolters Kluwer, 2020

MACEJKOVÁ, I. - BÁRÁNY, E. - BARICOVÁ, J. - FIAČAN, I. - HOLLÄNDER, P. - SVÁK, J. a kol. Zákon o Ústavnom súde Slovenskej republiky. Komentár. 1. vydanie. Bratislava : C. H. Beck, 2020

MLSNA, P. Ústavní soudnictví a dělba moci. In JIRÁSEK, J. (ed.): Ústavní základy soudní moci. Olomouc : Univerzita Palackého v Olomouci, 2009

NIKODÝM, D. Kompatibilita ústavného systému. In Právny obzor, 90, 2007, č. 5

PROCHÁZKA, R. Lud a sudcovia v konštitučnej demokracii. Plzeň : Aleš Čeněk, 2011

SVÁK, J. - CIBULKA, L. - KLÍMA, K. Ústavné právo Slovenskej republiky. V̌seobecná čast'. Bratislava : Bratislavská vysoká škola práva, 2008

SVÁK, J. - BALOG, B. Pokusy o ústavné zmeny v oblasti l’udských práv a realita. In 20 rokov Ústavy Slovenskej republiky. Košice : Univerzita Pavla Jozefa Šafárika v Košiciach, Právnická fakulta, 2012

SVÁK, J. - BALOG, B. Fragmentácia ústavy. In: Zmena práva. Bratislava : SAP, 2013

VOZÁR, J. Súd locuta kauza finita (niekol'ko poznámok k prijatému ústavnému zákonu č. 254/2006 Z. z.). In: Právny obzor, 2006, č. 3 